\title{
Some Studies on Milk Production and its Composition In Maghrebi She-Camel Under Farming And Traditional Pastoral Systems In Egypt
}

\author{
Mostafa $\mathrm{TH}^{1 *}$, El-Malky $\mathrm{OM}^{1}{ }^{1}$, Abd El-Salaam AM${ }^{1}$, Nabih AM $^{2}$ \\ ${ }^{1}$ Animal Production Research Institute, Agriculture Research Center, Ministry of Agriculture, Egypt. \\ ${ }^{2}$ Animal Reproduction Research Institute, Agriculture Research Center, Ministry of Agriculture, Egypt.
}

Received: November 15, 2017; Accepted: December 13, 2017; Published: December 18, 2017

*Corresponding author: Mostafa TH, Animal Production Research Institute, Agriculture Research Center, Ministry of Agriculture, Egypt, E-mail: dr.tarekhassan@yahoo.com

\section{Abstract}

This study aimed to determine the effect of management systems (farming and traditional pastoral system) and parity order on milk yield and composition of lactating Maghrebi camel. Total of forty lactating she-camels (Camelus dromedarius), (aging 5-12 years, weighing 370-590 kg, and between the first and eighth parities) were divided into two system groups (Farming and pastoral, $20 \mathrm{in}$ each). Each of farming or pastoral group was divided into four sub groups according to their parity, including 1-2, 3-4, 5-6 and 7-8parities, 5 animals in each. The obtained results revealed that overall mean of udder depth and circumference were higher $(\mathrm{P}<0.05)$ in farm than pastoral system. Udder length showed $(\mathrm{P}<0.05)$ an opposite trend, but udder width was not affected by management system. Overall mean of all udder measurements showed increase $(\mathrm{P}<0.05)$ by advancing parity. Effect of interaction between management system and animal parity on all udder measurements was not significant. Effect of management system on all teat measurements and milk vein diameter was not significant. However, these measurements increased $(\mathrm{P}<0.05)$ by advancing parity. Effect of interaction between management system and animal parity on all teat measurements and milk vein diameter was not significant. Overall mean of IgG, IgM, and IgA concentrations in colostrum of camels did not differ significantly $(\mathrm{P}<0.05)$ under both management systems. Concentration of IgG and IgA increased $(\mathrm{P}<0.05)$, while IgM insignificantly increased by advancing parity. Effect of interaction between management system and parity on immunoglobulin concentrations was not significant. Daily or total milk yield was higher $(\mathrm{P}<0.001)$ under farming more than pastoral system by about 26.12 and $13.41 \%$, respectively. Fat, protein, lactose, total solids and solids not-fat contents attained significantly higher values in milk of farming than in pastoral system. However, ash content showed an opposite $(\mathrm{P}<0.001)$ trend. Daily and total milk yield and its composition significantly increased by advancing parity. The interaction between management system and parity was not significant on milk yields and milk composition. Under pastoral system milk showed significantly higher contents of $\mathrm{Na}$ and $\mathrm{K}$ and significantly lower $\mathrm{P}$ and $\mathrm{Mg}$ than farm system. Milk Ca and chlorine contents were not affected by management system. By advancing animal parity, Ca and P contents increased (P < $0.05)$ up to 7-8 parities, while $\mathrm{Na}$ and $\mathrm{K}$ increased $(\mathrm{P}<0.05)$ up to 5-6 and 3-4 parities, respectively. Yet, $\mathrm{Mg}$ and chlorine contents were not affected significantly by parity. The interaction between management and parity was highly significant $(\mathrm{P}<0.001)$ only on $\mathrm{K}$ and $\mathrm{P}$, reflecting different trend of change in $\mathrm{K}$ and $\mathrm{P}$ contents in camels under farm and pastoral system by advancing parity.
\end{abstract}

This study could be recommended to increase awareness of the nomads about the importance of the effect of feeding system and parity on yield and nutritive value of camel milk produce for human consumption or suckling their newborns

Keywords: Maghrebi Camel; Management System; Parity; Milk Production;

\section{Introduction}

In many countries, dromedary camels are considered the strategic stockpile of food security, play an important role as a milk source and meat [1]. Increasing human population challenge food security and evoke the need to explore new resources of food, such as camel products [2]. Camel milk has an important role in human nutrition in many regions and also widely exploited for medication and human health such as anticancer anti-diabetic and hypo-allergic properties $[3,4,5,6]$. Camel sustains its productivity in difficult conditions and comparatively less affected by the adverse factors like feed and water shortage and water.
Several factors, such as type of food, are expected to affect the quality and composition of camel milk [7]. The information on the milk off take of camels varies according to the management of camels in their natural environment or under improved condition [8]. However, geographical origin and seasonal variations were found to be the most effective factors in camel milk composition [9]. Milk yield in the dromedary camels ranged between 3.5 and $20 \mathrm{~kg}$, varies greatly depending on the region $[10,11]$. Camel milk contained all the essential nutrients found in bovine milk [12]. Milk yield and composition in camels are influenced by environmental conditions, and time and number of milking [13].

Camel management systems are different from region to another, and very rare references on various quantitative traits 
of milk under different productive systems are available [14]. (Musaad, et al.) concluded that camel milk composition showed a wide variability in its constituents depending on the physiological, genetic and environmental factors. Milk yield of Maghrebi shecamels under traditional extensive conditions averages $2.0 \mathrm{l} / \mathrm{d}$ though, under more favorable conditions, it ranges between 6 and $12 \mathrm{l} / \mathrm{d}$ [15]. which suggest that the milk yield potential of this breed is greater than that recoded under the traditional extensive conditions. Variations observed in camel milk composition could be attributed to several factors such as feeding conditions and production systems $[16,17,18]$.

The objective of this study are evaluate the effect of different management system and parity order on milk yield, milk composition and bacteriological examination of Maghrebi camel under Egyptian conditions

\section{Materials and Methods}

This study was carried out in the Marsa Matrouh Governorate; $31^{\circ} 18^{\prime} 10.4^{\prime \prime} \mathrm{N} 27^{\circ} 05^{\prime} 45.5^{\prime \prime} \mathrm{E}$; (Northwest Egypt, $500 \mathrm{~km}$ from Cairo) during the period from November to Joule.

\section{Animals and experimental design}

Total of forty dairy Maghrebi she-camels (Camelus dromedarius), (aging 5-12 years, weighing 370-590 kg, and between the first and eighth parities) without history of diseases, were divided into two groups (G1 and G2). Twenty camels were chosen from a dairy farming system (Center of Studies and Development of Camel Production), belonging to the Animal Production Research Institute, Marsa Matrouh Governorate and twenty camels from a traditional pastoral herd in the desert areas inhabited by pastoral tribes (Bedouins) followed the same area (Marsa Matrouh Governorate). Each of farming or pastoral group was divided into four sub groups according to their parity, including 1-2, 3-4, 5-6 and 7-8parities, 5 animals in each. Camels in the first group $(\mathrm{G} 1, \mathrm{n}=20)$ were managed under farming system, all animals were kept in the experimental farm during the day, housed in semi-open barns all times and offered ration consisted of $4.5 \mathrm{~kg}$ DM of a forage mixture (Berseem hay and rice straw) and $3.5 \mathrm{~kg}$ DM of a commercial feed concentrate mixture composed of $25 \%$ wheat bran, $25 \%$ yellow corn, $9 \%$ uncorticated cotton seed meal, $20 \%$ barely, $15 \%$ rice brain,3\% molasses, $2 \%$ premix and $1 \%$ common salt (Table 1). Feeds were offered to animals twice daily. Free access to clean water was provided at all times by a water tanks.

Camels in the second group (G2, $\mathrm{n}=20$ ) were managed under traditional pastoral system; animals were brought to graze and browse the available plants and agricultural residues. The dominant vegetations of the natural pasture are Leucaena $(30 \%$ CF and 20\% CP), A triplex (20\% CF and 15\% CP), Mesquite (25\% $\mathrm{CF}$ and $23.5 \% \mathrm{CP})$, Kochia indica (14\% CF and $23 \% \mathrm{CP})$ and Alph alpha $(20 \%$ CF and 17\% CP).Climatic conditions, including ambient temperature (Max. and Min.) and relative humidity as well as calculated temperature-humidity index all over the year were 25.6 and $16.7{ }^{\circ} \mathrm{C}, 64.6$ and $58.1 \%$ ), respectively. However, photoperiod fluctuate between $11 \mathrm{~h}$ of light and $13 \mathrm{~h}$ of dark during this period.
Table 1: Chemical Composition of different feedstuffs used in feeding camels

\begin{tabular}{|c|c|c|c|}
\hline Item & CFM & BH & RS \\
\hline DM (\%) & 89.44 & 88.91 & 88.46 \\
\hline & \multicolumn{3}{|c|}{ Chemical analysis (\%): } \\
\hline OM & 92.43 & 82.92 & 82.24 \\
\hline CF & 8.85 & 24.91 & 35.69 \\
\hline CP & 12.24 & 13.85 & 2.53 \\
\hline EE & 4.64 & 1.14 & 1.52 \\
\hline NFE & 66.7 & 43.02 & 40.5 \\
\hline Ash & 7.57 & 17.08 & 19.76 \\
\hline
\end{tabular}

CFM: Concentrate Feed Mixture; BH: Berseem Hay; RS: Rice Straw.

\section{Colostrum analysis}

Colostrum samples were collected 3 times within one hour of parturition (first milking), 24 and 48 hours from each dam postpartum for immunoglobulin studies. Determination of immunoglobulins, including IgA, IgM and IgG in colostrum was applied by Bovine Radial Immune-Diffusion (RID) kit according to the procedure outlined by the manufacturer (The Binding Site Ltd, Birmingham, UK). The principle of the technique was derived from the work of (Mancini, et al.) and Fahey and McKelvey $[19,20]$.

\section{Udder measurements}

Udder and teat measurements were taken just before morning milking which coincided with approximately 16 hours milking interval. Each measurement in the present study was taken twice at the middle of the experimental period and the average of the two readings was then adopted as the base of calculations. The following udder and teat measurements were taken; udder depth: the distance between the udder attachment and the base of the teats, udder height: the distance from the ground to the base of the teats, and was measured as the distance from the ground to udder floor at the points directly in front of the fore and rear teats, teat length: the distance between the bases of the teat to the tip of the teat, by stretching the tape along the teat, teat diameter: with a vernier caliper at the middle point of the teat, and the distance between both fore, rear, right or left teats. Also, milk vein diameter was measured with a vernier caliper.

\section{Milking and milk samples}

All camels were handly milked twice a day. Milk yield was measured after the born calves were allowed to suckle colostrum from their dams for the first seven days. After each milking, milk was weighed on limited day for each week and then monthly milk yield was calculated for the lactation period.

\section{Milk composition}

Milk Samples $(30 \mathrm{ml})$ were collected from each lactating camel at milking time in clean glass bottles. Monthly sample of each camel were mixed from morning and evening milking, and taken for the determination of composition and physical characteristics of milk all over the lactation period. Whole milk samples were 
stored frozen at $-20^{\circ} \mathrm{C}$ without adding preservatives then the samples were heated to $40^{\circ} \mathrm{C}$ in a water bath and held at this temperature for $15 \mathrm{~min}$ for detection of protein, fat, lactose, total solids, solid not fat and ash using Lactoscan (Ultasonic Milk Analyzer, Bulgaria).

\section{Mineral content in milk}

Levels of $\mathrm{Ca}, \mathrm{K}, \mathrm{Na}$, and $\mathrm{Cl}$ in milk samples were determined with an atomic absorption spectrophotometer (Hitachi U-2000, Tokyo, Japan) according to standard methods [21]. Phosphorus content was determined spectrophotometrically using the procedure of Watanabe and Olsen [22].

\section{Statistical analysis}

Statistical analysis was carried out using the General Linear Model Program (GLM) of SAS [23]. Data were analyzed using the following model:

$$
\mathrm{YijK}=\mu+\mathrm{Ti}+\mathrm{DK}+\mathrm{eijK}
$$

Where $\mu=$ overall mean,

$\mathrm{Ti}=$ fixed effect of management,
DK= fixed effect of parity and

eijk $=$ Error.

The significant differences among means of parity groups were set at $\mathrm{P}<0.05$ using multiple range test of Duncan [24].

\section{Results and Discussion}

\section{Udder measurements}

Data showed that overall mean of udder depth and circumference were significantly $(\mathrm{P}<0.05)$ higher in camels of farm than pastoral system. However, udder length showed significantly $(\mathrm{P}<0.05)$ an opposite trend, but udder width was not affected by management system (Table 2 ).

It is worth noting that overall mean of all udder measurements showed significantly $(\mathrm{P}<0.05)$ gradual increase by advancing animal parity, being the lowest at 1-2 parities and the highest at 7-8 parities. On the other hand, the effect of interaction between management system and animal parity on all udder measurements was not significant, reflecting similar trend of changes in all measurements by advancing parity order udder both management system (Table 2).

Table 2: Effect of management system and parity on udder measurements (cm) in Maghrebi she camels.

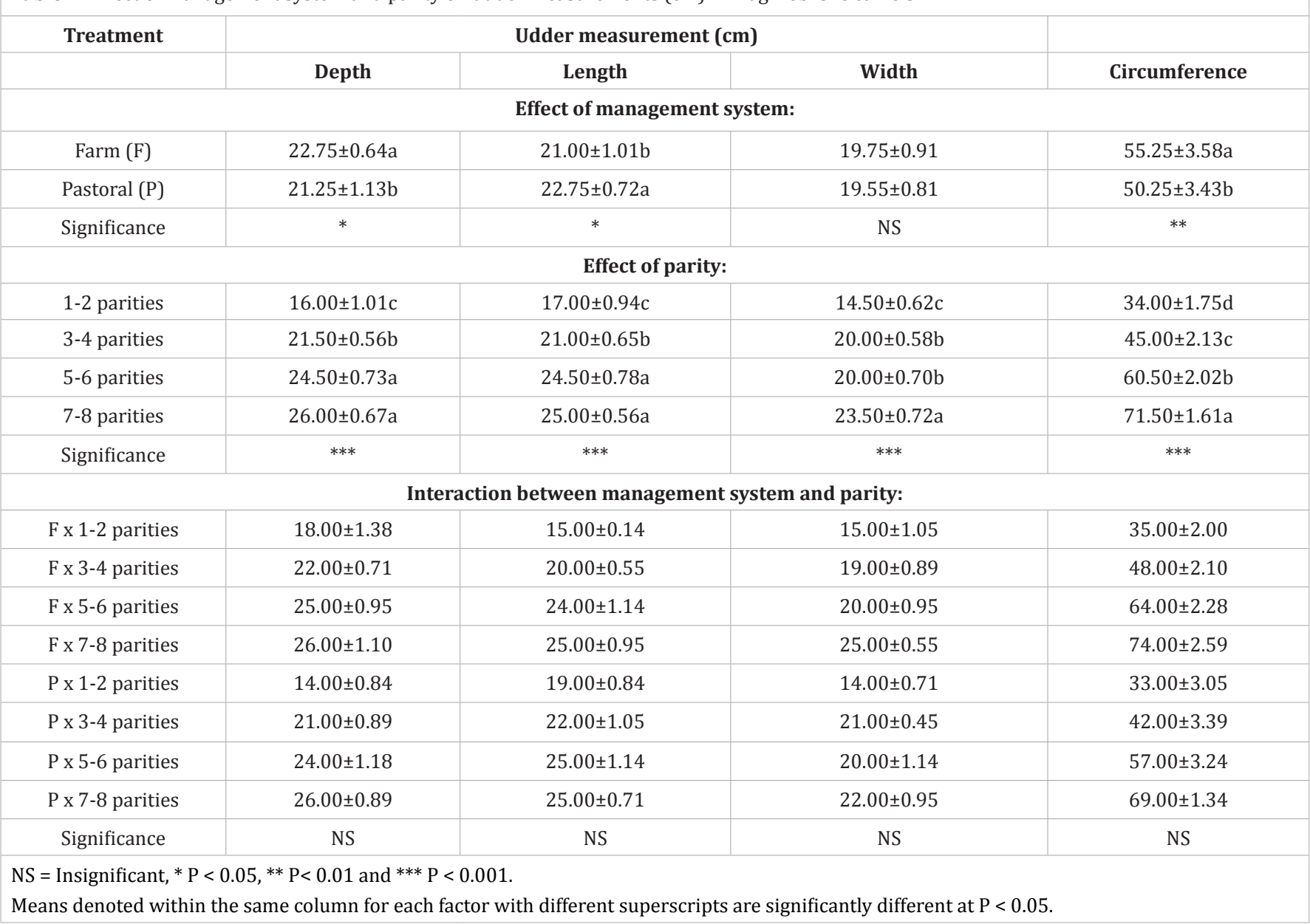




\section{Teat measurements:}

Effect of management system on all teat measurements and milk vein diameter (Table 3) was not significant. However, these measurements significantly $(\mathrm{P}<0.05)$ increased by advancing parity of camels, being with the highest values in camels with 7-8 parities. Also, the effect of interaction between management system and animal parity on all teat measurements and milk vein diameter was not significant, showing the same trend of increase in all measurements by advancing parity for camels in farm and pastoral systems (Table 2).

In lactating camels, (Zayeed, et al.) mentioned to a highly variations due to many factors such as breed, lactation stage, parity number and disease which can be influence on the size and length of udder and teats [25]. Similarly, Abdallah and Faye observed a clear variability in teats and udder length in 12 breeds of camels in Saudi Arabia, while some of the udder morphometric measurements of Lahween dromedary camel in Sudan have proved to possess an impact on their milk yield [26,27]. In addition, lactating camels are characterized by the development of the udder and milk veins [28].

Our results were less than that reported by (Ayadi, et al.) for udder measurements (cm) [29]. (Ayadi, et al.), also found positive relationships were detected between milk yield and udder morphology traits of dairy camels [29]. Udder height measured was similar to values reported by (Eisa, et al.) [27]. However, udder length and depth values were greater than the results previously reported by Abdallah and Faye in dromedary camels [26].

In accordance with the present results in this study, (Ayadi, et al.) and Abdallah and Faye found that teat length showed similar values in different breeds of camel in Saudi Arabia [26,29]. Meanwhile, the distance between teats was greater than the results previously reported by (Eisa, et al.) on camel [27]. Similar results were observed for milk vein diameter trait by (Eisa, et al.) in camels [27]. The well developed milk vein observed in our study may reflect a high yield milk secretion potential. In

Table 3: Effect of management system and parity on teat measurements (cm) in Maghrebi she camels.

\begin{tabular}{|c|c|c|c|c|c|c|c|c|c|c|}
\hline \multirow[t]{2}{*}{ Variable } & \multicolumn{3}{|l|}{ Fore teats } & \multicolumn{4}{|l|}{ Rear teats } & \multirow{2}{*}{\begin{tabular}{|l}
$\begin{array}{l}\text { Distance } \\
\text { between } \\
\text { lateral teats }\end{array}$ \\
Distance \\
in-between
\end{tabular}} & \multicolumn{2}{|c|}{ Milk vein diameter (MVD) } \\
\hline & Length & $\begin{array}{l}\text { Circum- } \\
\text { ferenc }\end{array}$ & Height & $\begin{array}{l}\text { Distance in- } \\
\text { between }\end{array}$ & Length & $\begin{array}{l}\text { Circum- } \\
\text { ferenc }\end{array}$ & Height & & & \\
\hline \multicolumn{11}{|c|}{ Effect of management system: } \\
\hline Farm $(F)$ & $3.75 \pm 0.43$ & $2.42 \pm 0.21$ & $93.10 \pm 2.20$ & $12.85 \pm 0.73$ & $5.55 \pm 0.50$ & $11.75 \pm 1.01$ & $91.65 \pm 2.15$ & $13.50 \pm 0.73$ & $3.90 \pm 0.22$ & $3.01 \pm 0.25$ \\
\hline Significance & NS & NS & NS & NS & NS & NS & NS & NS & NS & NS \\
\hline \multicolumn{11}{|c|}{ Effect of parity: } \\
\hline 1-2 parities & $1.90 \pm 0.23 \mathrm{~d}$ & $1.39 \pm 0.09 \mathrm{~d}$ & $81.10 \pm 1.68 \mathrm{c}$ & $9.10 \pm 0.56 \mathrm{~b}$ & $3.00 \pm 0.21 \mathrm{~d}$ & $6.90 \pm 0.43 \mathrm{~d}$ & $79.80 \pm 1.77 \mathrm{c}$ & $9.30 \pm 0.42 \mathrm{c}$ & $3.30 \pm 0.33 \mathrm{~b}$ & $1.59 \pm 0.12 \mathrm{c}$ \\
\hline 3-4 parities & $3.00 \pm 0.21 \mathrm{c}$ & $1.99 \pm 0.10 \mathrm{c}$ & $93.80 \pm 1.84 b$ & $12.90 \pm 0.65 a$ & $4.40 \pm 0.30 \mathrm{c}$ & $9.50 \pm 0.45 \mathrm{c}$ & $92.70 \pm 1.93 b$ & $13.90 \pm 0.62 b$ & $4.10 \pm 0.23 \mathrm{ab}$ & $2.45 \pm 0.12 b$ \\
\hline 5-6 parities & $4.30 \pm 0.42 b$ & $2.43 \pm 0.18 \mathrm{~b}$ & $100.20 \pm 1.38 \mathrm{a}$ & $13.70 \pm 0.70 \mathrm{a}$ & $7.00 \pm 0.42 b$ & $13.70 \pm 0.70 \mathrm{~b}$ & $98.60 \pm 1.24 \mathrm{a}$ & $14.70 \pm 0.78 \mathrm{ab}$ & $4.50 \pm 0.22 \mathrm{a}$ & $3.88 \pm 0.22 \mathrm{a}$ \\
\hline 7-8 parities & $6.40 \pm 0.37 \mathrm{a}$ & $3.65 \pm 0.18 \mathrm{a}$ & $100.90 \pm 0.80 \mathrm{a}$ & $15.10 \pm 0.97 \mathrm{a}$ & $8.10 \pm 0.27 \mathrm{a}$ & $17.20 \pm 0.48$ & $99.30 \pm 0.74 a$ & $15.80 \pm 0.55 \mathrm{a}$ & $4.60 \pm 0.40 \mathrm{a}$ & $4.19 \pm 0.14 \mathrm{a}$ \\
\hline Significance & *** & $* * *$ & $* * *$ & $* * *$ & $* * *$ & $* * *$ & $* * *$ & $* * *$ & $*$ & $* * *$ \\
\hline \multicolumn{11}{|c|}{ Interaction between management system and parity: } \\
\hline $\begin{array}{l}\text { F x 1-2 } \\
\text { parities }\end{array}$ & $2.00 \pm 0.31$ & $1.46 \pm 0.13$ & $79.40 \pm 1.65$ & $9.20 \pm 0.860$ & $3.00 \pm 0.31$ & $6.40 \pm 0.67$ & $78.00 \pm 1.51$ & $9.00 \pm 70$ & $3.20 \pm 0.48$ & $1.72 \pm 0.1$ \\
\hline $\begin{array}{l}\mathrm{F} \times 3-4 \\
\text { parities }\end{array}$ & $2.80 \pm 0.20$ & $2.08 \pm 0.08$ & $91.60 \pm 2.06$ & $13.00 \pm 0.94$ & $4.60 \pm 0.50$ & $9.20 \pm 0.58$ & $90.60 \pm 2.15$ & $14.40 \pm 0.87$ & $4.20 \pm 0.37$ & $2.40 \pm 0.1$ \\
\hline $\begin{array}{l}\text { F x 5-6 } \\
\text { parities }\end{array}$ & $3.60 \pm 0.40$ & $2.32 \pm 0.22$ & $99.80 \pm 2.74$ & $14.20 \pm 1.20$ & $6.60 \pm 0.74$ & $14.80 \pm 1.01$ & $98.00 \pm 2.40$ & $15.40 \pm 1.07$ & $4.20 \pm 0.37$ & $3.80 \pm 0.35$ \\
\hline $\begin{array}{l}\mathrm{F} \times 7-8 \\
\text { parities }\end{array}$ & $6.60 \pm 0.50$ & $3.80 \pm 0.22$ & $101.60 \pm 1.02$ & $15.0 \pm 1.48$ & $8.00 \pm 0.44$ & $16.60 \pm 0.81$ & $100.00 \pm 0.89$ & $15.20 \pm 0.96$ & $4.00 \pm 0.44$ & $4.10 \pm 0.24$ \\
\hline $\begin{array}{l}\mathrm{F} \times 1-2 \\
\text { parities }\end{array}$ & $1.80 \pm 0.37$ & $1.32 \pm 0.14$ & $82.80 \pm 2.98$ & $9.00 \pm 0.83$ & $3.00 \pm 0.31$ & $7.400 \pm 0.50$ & $81.60 \pm 3.18$ & $9.60 \pm 0.50$ & $3.40 \pm 0.50$ & $1.46 \pm 0.18$ \\
\hline $\begin{array}{l}\mathrm{F} \times 3-4 \\
\text { parities }\end{array}$ & $3.20 \pm 0.37$ & $1.90 \pm 0.18$ & $96.00 \pm 2.93$ & $12.80 \pm 1.01$ & $4.20 \pm 0.37$ & $9.80 \pm 0.73$ & $94.80 \pm 3.15$ & $13.40 \pm 0.92$ & $4.00 \pm 0.31$ & $2.50 \pm 0.19$ \\
\hline $\begin{array}{l}\mathrm{F} \times 7-8 \\
\text { parities }\end{array}$ & $6.20 \pm 0.58$ & $3.50 \pm 0.302$ & $100.20 \pm 1.28$ & $15.20 \pm 1.42$ & $8.20 \pm 0.37$ & $17.80 \pm 0.48$ & $98.60 \pm 1.20$ & $16.40 \pm 0.50$ & $5.20 \pm 0.58$ & $4.28 \pm 0.18$ \\
\hline Significance & NS & NS & NS & NS & NS & NS & NS & NS & NS & NS \\
\hline
\end{tabular}


agreement with the present results regarding the effect of parity on udder measurements, Osman found marked trend of increase in all uder and teat measurements as well as in diameter and length of milk vein by advancing parity, stage of lactations and age of camel [30].

\section{Immunoglobulin concentration in camel colostrum}

(Table 4) showed that overall mean of IgG, IgM, and IgA concentrations in colostrum of camels did not differ significantly $(\mathrm{P}<0.05)$ under both management systems. $)$ However, concentration of IgG and IgA significantly $(\mathrm{P}<0.05)$ increased, while IgM insignificantly increased by advancing animal parity. Meanwhile, the effect of interaction between management system and parity on immunoglobulin concentrations was not significant.

Concentration of IgG in camel milk is $1.64 \mathrm{mg} / \mathrm{ml}$ as compared to $0.70,0.67,0.55,0.63$ and $0.86 \mathrm{mg} / \mathrm{ml}$ for goat, cow, sheep, buffalo and human milk, respectively [31]. In spite of the higher mean IgG concentration in the Dromedary camels, found that mean IgG concentration in raw camel milk was $0.718 \pm 0.330$ $\mathrm{mg} / \mathrm{m}$, but IgG concentration differed for region [32]. They also found seasonal change in IgG content, being higher in winter than in summer. Concentration of IgG decreased regularly $(\mathrm{P}<0.001)$ throughout the year, with the highest value in January and the lowest in July.
It is highly required to investigate colostrum under farming and traditional systems to evaluate the impact of this variable on neonatal viability rate. In this respect, (Bernabucci, et al.) mentioned that multiple factors influence the production and the composition of colostrum, including the species, breed, health status of the mammal, feeding practices, and time collected post-parturition [33]. However, (El-Hatmi et al.) found that concentration of IgG at first milking in Tunisian camels dropped abruptly in the subsequent milkings [34]. Fahmy and Maha found that the concentration of IgG1 decreased by $94 \%$ within the whole period of lactation in dromedary camel (Camelus Dromedarius) reared in Marsa Matroh governorate during the first season of lactation [35]. (Mackle, et al.) showed that a pasture supplementing with maize grain and silage led to slightly decreasing of IgG content [36]. Also, In bovin, (Król, et al.) reported that feeding system has the major impact on the milk yield and its chemical composition [37]. Milk of cows grazing the pasture were characterized by a higher content of IgG. Osman mentioned that individual animals showed a wide range of colostrum composition which suggests a prominent role of animal individuality [38]. The chemical characteristics of colostrum were greatly affected by colostral days and slightly by lactation number.

\section{Milk yield and composition}

Data in (Table 5) showed that daily or total milk yield was

Table 4: Effect of management system and parity on immunoglobulin concentration in colostrum in Maghrebi she camels.

\begin{tabular}{|c|c|c|c|}
\hline Variable & $\operatorname{IgG}(\mathrm{g} / \mathrm{dl})$ & $\operatorname{IgM}(g / d l)$ & $\operatorname{IgA}(\mathrm{g} / \mathrm{dl})$ \\
\hline \multicolumn{4}{|c|}{ Effect of management system: } \\
\hline Farm system (F) & $33.69 \pm 2.31$ & $4.93 \pm 0.20$ & $2.92 \pm 0.24$ \\
\hline Pastoral system (P) & $32.0 \pm 2.09$ & $4.98 \pm 0.21$ & $3.11 \pm 0.20$ \\
\hline Significance & NS & NS & NS \\
\hline \multicolumn{4}{|c|}{ Effect of parity: } \\
\hline $1 \cdot 2$ parities & $20.54 \pm 0.79^{d}$ & $4.49 \pm 0.32$ & $2.49 \pm 0.27^{b}$ \\
\hline 3.4 parities & $28.99 \pm 0.89^{c}$ & $5.43 \pm 0.24$ & $2.73 \pm 0.25^{b}$ \\
\hline 56 parities & $36.96 \pm 1.56^{\mathrm{b}}$ & $4.88 \pm 0.15$ & $3.60 \pm 0.30^{\mathrm{a}}$ \\
\hline 7-8 parities & $44.89 \pm 0.91^{\mathrm{a}}$ & $5.02 \pm 0.34$ & $3.23 \pm 0.33^{\mathrm{ab}}$ \\
\hline Significance & $* * *$ & NS & $*$ \\
\hline \multicolumn{4}{|c|}{ Interaction between breeding system and parity } \\
\hline $\mathrm{F} \times 12$ parities & $20.28 \pm 1.21$ & $4.36 \pm 0.48$ & $2.14 \pm 0.28$ \\
\hline $\mathrm{F} \times 3.4$ parities & $29.36 \pm 1.24$ & $5.20 \pm 0.35$ & $2.48 \pm 0.26$ \\
\hline F x 5.6 parities & $39.64 \pm 1.78$ & $5.02 \pm 0.25$ & $4.10 \pm 0.50$ \\
\hline F x 7-8 parities & $45.48 \pm 1.34$ & $5.14 \pm 0.50$ & $2.94 \pm 0.41$ \\
\hline P $\times 12$ parities & $20.80 \pm 1.14$ & $4.62 \pm 0.50$ & $2.84 \pm 0.44$ \\
\hline $\mathrm{P} \times 3.4$ parities & $28.62 \pm 1.40$ & $5.66 \pm 0.32$ & $2.98 \pm 0.41$ \\
\hline$P \times 56$ parities & $34.28 \pm 2.06$ & $4.74 \pm 0.19$ & $3.10 \pm 0.16$ \\
\hline P x 7-8 parities & $44.30 \pm 1.34$ & $4.90 \pm 0.53$ & $3.52 \pm 0.53$ \\
\hline Significance & NS & NS & NS \\
\hline
\end{tabular}

NS $=$ Insignificant, $* \mathrm{P}<0.05$ and ${ }^{* * *} \mathrm{P}<0.001$.

Means denoted within the same column for each factor with different superscripts are significantly different at $\mathrm{P}<0.05$. 
significantly $(\mathrm{P}<0.001)$ higher for she-camels under farming systems more than those under traditional pastoral system by about 26.12 and $13.41 \%$, respectively. Also, camel milk composition showed significant differences between both management systems. Fat, protein, lactose, total solids and solids not-fat contents attained significantly higher values in milk of farming system as compared with the traditional pastoral system. However, ash content showed significantly $(\mathrm{P}<0.001)$ an opposite trend. As affected by animal parity, data in (Table 5) cleared that significant increase in daily and total milk yield and its composition by advancing parity. The interaction between management system and parity was not significant on milk yields and milk composition.

It is worth noting that increasing milk yield of camels under farm system was associated with significant increase in depth and circumference of udder with insignificant changes in teat characteristics as compared to pastoral camels. Also, increasing milk yield by advancing camel parity, regardless management system, was related to developmental changes in udder and teat measurements by age progress. These results indicated significant effects of camel management system on yield and composition of milk. Remarkable variation in feeding system was achieved in camel farms or during grazing. In this study, camels were under good feeding system in the farm, while camels under pastoral system were under poor feeding of fry and wet shrubs and desert shrubs and insufficient in drinking water (thirst). The most important factor in camel milk for peoples living in dry zone is its water content [39].

In similarity with the present results, (Bakheit, et al.) found that average daily milk yield was $6.85 \pm 1.32$ and $3.14 \pm 0.66$ liter

Table 5: Milk yield and chemical composition of Maghrebi she camels as affected by management system, camel parity and their interaction

\begin{tabular}{|c|c|c|c|c|c|c|c|c|}
\hline \multirow{2}{*}{ Variable } & \multicolumn{2}{|c|}{ Milk yield (kg) } & \multicolumn{6}{|c|}{ Milk composition (\%) } \\
\hline & Daily & Total & Fat & Protein & Lactose & Ash & Total solids & Solid not-fat \\
\hline \multicolumn{9}{|c|}{ Effect of management system: } \\
\hline Farm system (F) & $7.29 \pm 0.39^{a}$ & $496.0 \pm 26.18^{a}$ & $2.52 \pm 0.11^{\mathrm{a}}$ & $3.08 \pm 0.15^{\mathrm{a}}$ & $5.77 \pm 0.17^{\mathrm{a}}$ & $0.80 \pm 0.04^{b}$ & $12.17 \pm 0.38^{\mathrm{a}}$ & $9.64 \pm 0.32^{\mathrm{a}}$ \\
\hline $\begin{array}{l}\text { Pastoral system } \\
\text { (P) }\end{array}$ & $5.78 \pm 0.26^{\mathrm{b}}$ & $437.4 \pm 33.04^{b}$ & $1.87 \pm 0.05^{b}$ & $2.64 \pm 0.11^{\mathrm{b}}$ & $5.30 \pm 0.24^{\mathrm{b}}$ & $1.004 \pm 0.03^{\mathrm{a}}$ & $10.81 \pm 0.35^{b}$ & $8.94 \pm 0.34^{\mathrm{b}}$ \\
\hline \multicolumn{9}{|l|}{ Effect of parity: } \\
\hline 1-2 parities & $4.86^{\mathrm{c}} \pm 0.26 \mathrm{c}$ & $282.7 \pm 27.76^{c}$ & $1.94 \pm 0.15^{c}$ & $2.28 \pm 0.07^{\mathrm{d}}$ & $4.34 \pm 0.23^{b}$ & $0.75 \pm 0.06^{\mathrm{b}}$ & $9.32 \pm 0.21^{\mathrm{c}}$ & $7.37 \pm 0.25^{c}$ \\
\hline $3-4$ parities & $6.22^{\mathrm{b}} \pm 0.37 \mathrm{~b}$ & $478.6 \pm 26.60^{b}$ & $2.04 \pm 0.07^{\mathrm{bc}}$ & $2.59 \pm 0.11^{c}$ & $5.60 \pm 0.25^{\mathrm{a}}$ & $0.88 \pm 0.06^{\mathrm{a}}$ & $11.12 \pm 0.34^{\mathrm{b}}$ & $9.08 \pm 0.29^{b}$ \\
\hline $5-6$ parities & $6.90^{\mathrm{b}} \pm 0.51 \mathrm{~b}$ & $508.3 \pm 19.68^{\mathrm{b}}$ & $2.33 \pm 0.16^{\mathrm{ab}}$ & $3.00 \pm 0.14^{\mathrm{b}}$ & $6.09 \pm 0.17^{\mathrm{a}}$ & $0.97 \pm 0.03^{\mathrm{a}}$ & $12.41 \pm 0.35^{\mathrm{a}}$ & $10.07 \pm 0.27^{a}$ \\
\hline 7-8 parities & $8.15^{\mathrm{a}} \pm 0.28 \mathrm{a}$ & $597.3 \pm 12.32^{\mathrm{a}}$ & $2.46 \pm 0.18^{\mathrm{a}}$ & $3.55 \pm 0.17^{\mathrm{a}}$ & $6.08 \pm 0.14^{\mathrm{a}}$ & $0.99 \pm 0.04^{\mathrm{a}}$ & $13.09 \pm 0.36^{\mathrm{a}}$ & $10.63 \pm 0.22^{\mathrm{a}}$ \\
\hline \multicolumn{9}{|c|}{ Interaction between management system and parity: } \\
\hline $\mathrm{F} \times 12$ parities & $4.94 \pm 0.51$ & $351.2 \pm 31.77$ & $2.18 \pm 0.23$ & $2.26 \pm 0.14$ & $4.66 \pm 0.27$ & $0.66 \pm 0.12$ & $9.76 \pm 0.17$ & $7.58 \pm 0.33$ \\
\hline $\mathrm{F} \times 3.4$ parities & $7.14 \pm 0.39$ & $505.0 \pm 44.11$ & $2.24 \pm 0.04$ & $2.88 \pm 0.09$ & $5.95 \pm 0.14$ & $0.76 \pm 0.07$ & $11.83 \pm 0.14$ & $9.59 \pm 0.18$ \\
\hline$F \times 5.6$ parities & $8.26 \pm 0.44$ & $515.0 \pm 33.90$ & $2.72 \pm 0.19$ & $3.20 \pm 0.11$ & $6.35 \pm 0.22$ & $0.89 \pm 0.01$ & $13.17 \pm 0.33$ & $10.45 \pm 0.24$ \\
\hline F x 7-8 parities & $8.82^{\mathrm{a}} \pm 0.25$ & $613.0 \pm 11.79$ & $2.95 \pm 0.19$ & $3.97 \pm 0.18$ & $6.11 \pm 0.08$ & $0.89 \pm 0.03$ & $13.91 \pm 0.34$ & $10.96 \pm 0.21$ \\
\hline $\mathrm{P} \times 12$ parities & $4.78 \pm 0.22$ & $214.2 \pm 10.61$ & $1.71 \pm 0.16$ & $2.31 \pm 0.07$ & $4.02 \pm 0.36$ & $0.84 \pm 0.04$ & $8.88 \pm 0.30$ & $7.17 \pm 0.41$ \\
\hline $\mathrm{P} \times 3-4$ parities & $5.30 \pm 0.25$ & $452.2 \pm 29.85$ & $1.84 \pm 0.04$ & $2.31 \pm 0.09$ & $5.25 \pm 0.46$ & $1.01 \pm 0.08$ & $10.42 \pm 0.51$ & $8.58 \pm 0.49$ \\
\hline$P \times 5.6$ parities & $5.54 \pm 0.28$ & $501.6 \pm 23.92$ & $1.94 \pm 0.11$ & $2.80 \pm 0.26$ & $5.85 \pm 0.25$ & $1.07 \pm 0.03$ & $11.66 \pm 0.40$ & $9.71 \pm 0.47$ \\
\hline P x 7-8 parities & $7.48 \pm 0.28$ & $581.6 \pm 20.52$ & $1.98 \pm 0.07$ & $3.15 \pm 0.16$ & $6.05 \pm 0.30$ & $1.11 \pm 0.04$ & $12.28 \pm 0.40$ & $10.30 \pm 0.36$ \\
\hline Significance & $* *$ & NS & NS & NS & NS & NS & NS & NS \\
\hline
\end{tabular}

NS = Insignificant and ${ }^{* * *} \mathrm{P}<0.001$.

Means denoted within the same column for each factor with different superscripts are significantly different at $\mathrm{P}<0.05$.

for semi-intensive and traditional system, respectively with highly significant $(\mathrm{P}<0.001)$ differences [40]. The increase in average daily milk yield amounted to $53 \%$ under semi-intensive system compared to those under traditional system. The present values of milk composition are in agreement with the results of (Abdalla et al.), who reported that milk of Maghrebi she-camels under normal condition contained 3.01, 3.06, 0.69, 4.33, and 11.06\%for protein, fat, ash, lactose and total solids contents, respectively
[41]. Also, Obied and Hakem found a wide range of variation in the chemical composition of milk among different management systems especially under uncontrolled environmental condition as is mostly the case locally and the significant effect between the mean values of the two milk groups at $(\mathrm{P}<0.05)$ were found to be in water, lactose, ash and total solids [42]. In this respect, (Shuiep et al.) revealed that, camel milk under semi intensive system showed significantly $(P<0.05)$ higher total protein, 
solids not-fat and lactose contents. Whereas, fat was significantly $(\mathrm{P}<0.05)$ higher in milk samples collected from traditional nomadic system [43]. Several authors reported that camel milk composition was influenced by regional differences including feeding conditions (Al-Haj and Al-Kanhal, et al.); (Babiker and El Zubeir, et al.), or management system, season, stage of lactation and calving number (Riyadh, et al.), and geographical locations or feeding conditions $[9,44,45,46,47]$. On the other hand, Dowelmadina found that the highest percentages of fat, protein, lactose, total solids and solids not fat were recorded for the camel in the traditional nomadic system, followed by the semi intensive system [48]. Finally, Mustafa found that mean values of solid nonfat; crude fat; crude protein and lactose were (9.13 and 8.42\%); (5.39 and 1.71\%); (4.94 and 4.57\%) and (3.64 and 3.24\%) in milk of camels kept under traditional pastoral and farming system, respectively [49].

\section{Mineral content in milk}

Lower inorganic $\mathrm{P}$ and $\mathrm{Mg}$ than those reared under farm system. However, milk $\mathrm{Ca}$ and chlorine contents were not affected by management system. These trends may be due to the differences of the feeding and water intake.

By advancing animal parity, $\mathrm{Ca}$ and $\mathrm{P}$ contents significantly ( $\mathrm{P}$ $<0.05$ ) increased up to 7-8 parities, while Na and K significantly
( $\mathrm{P}<0.05$ ) increased up to 5-6 and 3-4 parities, respectively. Yet, $\mathrm{Mg}$ and chlorine contents were not affected significantly by parity. The interaction between management and parity was highly significant $(\mathrm{P}<0.001)$ only on $\mathrm{K}$ and $\mathrm{P}$, reflecting different trend of change in $\mathrm{K}$ and $\mathrm{P}$ contents in camels under farm and pastoral system by advancing camel parity (Table 6).

It was reported that the major mineral contents $(\mathrm{Ca}, \mathrm{P}, \mathrm{Na}$, and $\mathrm{K}$ ) of dromedary camel milk showed a large variation among different studies due to breed, feeding, stage of lactation, drought conditions, or analytical procedures [50,51]. In agreement with this study, Obied and Hakem found that the desert camel bulk milk had significantly higher amount of $\mathrm{Ca}, \mathrm{Na}$ and $\mathrm{K}$ than in farm camel milk [42]. Shawket and Ibrahem found increased (P $<0.05$ ) content of macro-elements ( $\mathrm{Na}, \mathrm{K}$ and $\mathrm{Ca} \%)$ in milk of camels fed ad lib. on fresh Atriplex halimus due to higher $\mathrm{Na}, \mathrm{K}$ and Ca contents in Atriplex than in berseem hay [52].

On the other hand, Elnour and Bakheit indicated that mineral contents in camel milk were affected by parity $[53,54]$. Contents of $\mathrm{P}, \mathrm{Na}$ and $\mathrm{K}$ markedly increased with increasing parity number. Content of P in milk of camels at one and three parities were 1.13 and $1.4 \%$, respectively, increased to $1.8 \%$ at advanced perities. Content of $\mathrm{Na}(0.65-0.95 \%)$ and $\mathrm{K}(3.37-4.1 \%)$ increased, while Ca content (5.2-1.55\%) markedly decreased (5.2 and $1.55 \%$ ) by

Table 6: Mineral content in milk of Maghrebi camels affected by management system, camel parity and their interaction.

\begin{tabular}{|c|c|c|c|c|c|c|}
\hline \multirow{2}{*}{ Variable } & \multicolumn{6}{|c|}{ Mineral content (mg/dl) } \\
\hline & Calcium & Sodium & Potassium & Inorganic phosphors & Magnesium & Chlorine \\
\hline \multicolumn{7}{|c|}{ Effect of management system: } \\
\hline Farm system (F) & $188.27 \pm 4.34$ & $75.38 \pm 2.97^{b}$ & $87.83 \pm 1.49^{b}$ & $117.74 \pm 3.07^{b}$ & $11.80 \pm 0.34^{\mathrm{a}}$ & $100.24 \pm 0.54$ \\
\hline Pastoral system (P) & $190.77 \pm 3.61$ & $81.98 \pm 3.31^{\mathrm{a}}$ & $92.22 \pm 3.06^{\mathrm{a}}$ & $102.47 \pm 1.79^{a}$ & $7.38 \pm 0.17^{\mathrm{b}}$ & $101.38 \pm 0.42$ \\
\hline Significance & NS & $* *$ & $*$ & $* * *$ & $* * *$ & NS \\
\hline \multicolumn{7}{|l|}{ Effect of parity } \\
\hline 12 parities & $167.55 \pm 4.68^{\mathrm{c}}$ & $65.30 \pm 2.10^{\mathrm{b}}$ & $75.43 \pm 2.05^{b}$ & $104.07 \pm 2.21^{c}$ & $9.53 \pm 0.96$ & $99.80 \pm 0.49$ \\
\hline $3-4$ parities & $190.25 \pm 4.44^{b}$ & $68.45 \pm 2.70^{\mathrm{b}}$ & $94.36 \pm 2.35^{\mathrm{a}}$ & $103.62 \pm 2.26^{c}$ & $9.51 \pm 0.66$ & $101.07 \pm 0.65$ \\
\hline $5 \% 6$ parities & $197.61 \pm 3.17^{\mathrm{ab}}$ & $88.39 \pm 2.12^{\mathrm{a}}$ & $93.26 \pm 2.35^{\mathrm{a}}$ & $111.20 \pm 4.72^{\mathrm{b}}$ & $9.64 \pm 0.95$ & $100.28 \pm 0.81$ \\
\hline 7-8 parities & $202.66 \pm 1.81^{a}$ & $92.58 \pm 2.91^{\mathrm{a}}$ & $97.05 \pm 1.80^{\mathrm{a}}$ & $121.55 \pm 4.84^{\mathrm{a}}$ & $9.66 \pm 0.71$ & $102.09 \pm 0.66$ \\
\hline \multicolumn{7}{|c|}{ Interaction between management system and parity: } \\
\hline F x 12 parities & $158.48 \pm 3.32^{\mathrm{d}}$ & $62.22 \pm 2.68$ & $79.55 \pm 1.37^{\mathrm{e}}$ & $106.53 \pm 2.47^{\mathrm{bc}}$ & $12.02 \pm 0.97$ & $99.94 \pm 0.93$ \\
\hline $\mathrm{F} \times 3-4$ parities & $196.88 \pm 5.79^{\mathrm{ab}}$ & $66.23 \pm 3.98$ & $90.51 \pm 2.32^{\mathrm{cd}}$ & $106.97 \pm 1.82^{\mathrm{bc}}$ & $11.36 \pm 0.48$ & $100.52 \pm 1.23$ \\
\hline $\mathrm{F} \times 5^{-6}$ parities & $198.66 \pm 3.71^{\mathrm{a}}$ & $86.40 \pm 2.82$ & $88.97 \pm 3.06^{d}$ & $124.34 \pm 3.16^{\mathrm{a}}$ & $12.23 \pm 0.85$ & $99.56 \pm 1.41$ \\
\hline F x 7-8 parities & $199.06 \pm 1.75^{a}$ & $86.65 \pm 3.13$ & $92.29 \pm 1.13^{\mathrm{bcd}}$ & $133.14 \pm 5.39^{a}$ & $11.58 \pm 0.44$ & $100.94 \pm 0.95$ \\
\hline $\mathrm{P} \times 122$ parities & $176.64 \pm 6.82^{c}$ & $68.38 \pm 2.82$ & $71.32 \pm 2.93^{f}$ & $101.61 \pm 3.59^{\mathrm{bc}}$ & $7.04 \pm 0.32$ & $99.66 \pm 0.48$ \\
\hline $\mathrm{P} \times 3-4$ parities & $183.62 \pm 5.76^{b c}$ & $70.67 \pm 3.82$ & $98.21 \pm 3.49^{\mathrm{ab}}$ & $100.27 \pm 3.77^{b c}$ & $7.67 \pm 0.18$ & $101.62 \pm 0.50$ \\
\hline$P \times 5.6$ parities & $196.56 \pm 5.57^{\mathrm{ab}}$ & $90.39 \pm 3.22$ & $97.56 \pm 2.54^{\mathrm{abc}}$ & $98.07 \pm 2.02^{c}$ & $7.05 \pm 0.08$ & $101.0 \pm 0.87$ \\
\hline $\mathrm{P} \times 7-8$ parities & $206.26 \pm 2.30^{\mathrm{a}}$ & $98.50 \pm 3.30$ & $101.80 \pm 1.42^{\mathrm{a}}$ & $109.95 \pm 3.09^{b}$ & $7.76 \pm 0.54$ & $103.24 \pm 0.67$ \\
\hline Significance & $*$ & NS & $* *$ & $* *$ & NS & NS \\
\hline
\end{tabular}

NS = Insignificant, $* \mathrm{P}<0.05,{ }^{* *} \mathrm{P}<0.01$ and ${ }^{* * *} \mathrm{P}<0.001$.

Means denoted within the same column for each factor with different superscripts are significantly different at $\mathrm{P}<0.05$. 
increasing camel parity. Results in (Table 6) revealed that camels reared under traditional pastoral system showed significantly higher contents of $\mathrm{Na}$ and $\mathrm{K}$ and significantly

\section{Conclusions}

Based on the foregoing results, both parity order and management system play an important role in productive performance of Maghrebi lactating camels, in terms of remarkable increase in milk yield and production of good quality milk of Maghrebi camel under farm system as compared to pastoral system and by advancing parity order, without obvious effect was found on level of immunoglobulins in milk.

\section{References}

1. El-Bahrawy KA, Khalifa MA, Rateb SA. Recent advances in dromedary camel reproduction: An Egyptian field experience. Emir. J. Food Agric.2015;27(4):350-354.

2. Faye B, Konuspayeva G. The sustainability challenge to the dairy sector the growing importance of non-cattle milk production worldwide. Int. Dairy J.2012;24(2)50-56.

3. Agrawal RP, Jain S, Shah S, Chopra A, Agarwal V. Effect of camelmilk on glycemic control and insulin requirement in patients with type 1 diabetes: 2-years randomized controlled trial. Eur. J. Clin. Nutr.2011;65(9):1048-1052.

4. Magjeed N. Corrective effect of milk camel on some cancer biomarkers in blood of rats intoxicated with aflatoxin B1. J. SaudiChem. Soc. 2005;9(2):253-263.

5. Mal G, Sena DS, Jain VK, Sahani MS. Therapeutic value of camel milk as a nutritional supplement for multiple drug resistant (MDR) tuberculosis patients, Isr.J. Vet. Med.2006;61:88-91.

6. Shabo Y. Barzel R, Margoulis M, Yagil R. Camel milk for food allergies in children. Immun. Allerg.2005;7:796-798.

7. Mustafa B, EHA M, Atti AKA, Abunokhila AM, Rahmatalla SA. Elterife AMA. Effect of parity on milk yield and dam body change postpartum of dromedary camel (Camelus dromedarius) under farming system in Sudan, I.J.A.P.B.C.2015;4(1): 131-137.

8. Yagil, R. (1982). Camels and camel milk. Rome, Italy, FAO, 69 P(FAO animal Production and Health Paper $n^{\circ} 26$ ).

9. Konuspayeva G, Faye B, Loiseau G. The composition of camel milk, a meta-analysis of the literature data, J. Food Comp. Anal. 2009;22 (2):95101.

10.Jianlin H. Camelids. In: Pond, W.G., Bell, A.W. (Eds.), Encycl. Anim.Sci. Marcel Dekker, Inc., New York,2005;187-190.

11. Kamoun, M. and Jemmali, B. (2012). Milk yield and characteristics of Tunisian camel. J. Anim. Sci. 1:12-13.

12. Narmuratova M, Konuspayeva G, Loiseau G, Serikbaeva A, Barouh N ,Montet D, et al. Fatty acids composition of dromedary Bactrian camel milk in Kazakhstan, J. Camel Pract. Res.2006;13(1):45-50.

13. Aljumaah RS, Almutairi F, Ayadi M, Alshaikh M, Aljumaah A, Hussein M. Factors influencing the prevalence of subclinical mastitisin lactating dromedary camels in Riyadh region, Saudi Arabia. Trop.Anim. Health Prod.2011;43(8):1605-1610.

14. Eha M, Mustafa B, and Atti AKA. Milk composition of the udder quarters of she-camel (Camelus dromedarius) raised under intensive farming system, I.J.S.K.2016;5(1):9-12.
15. Ayadi M, Hammadi M, Khorchani T ,Barmat A, Atigui M, Caja G. Effects of milking interval and cisternal udder evaluation in Tunisian Maghrebi dairy dromedaries (Camelus dromedarius L.). J. Dairy Sci.2009;92(4):1452-1459.

16. Aljumaah RS, Almutairi FF, Ismail E, Alshaikh MA, Sami A , Ayadi M. Effects of production system, breed, parity and stage of lactationon milk composition of dromedary camels in Saudi Arabia. J. Anim. Vet. Adv.2012;11:141-147.

17. Bakheit SA, Majid AM, Abu-Nikhila AM. Camels (Camelus dromedarius) under pastoral systems in North Kordofan, Sudan: Seasonal and parity effects on milk composition. J. Camelid Sci.2008;1:32-36.

18. Khaskheli M, Arain MA, Chaudhry S, Soomro AH, Qureshi TA. Physicochemical quality of camel milk. J. Agric. Soc. Sci.2005; 2:164166.

19. Fahey JL, McKelvey EM. Quantitative determination of serum Immunoglobulins in antibody agar plates. J. Immunol.1965;94:84-90.

20. Mancini G, Carbonara AO, Hermans D. Immunochemical quantitation of antigens by single radial immunodiffusion. Immunochem.1965;2(3):235-254.

21.AOAC.Official Methods of Analysis. 13th ed. Association of Official Analytical Chemists, Washington, DC.1980.

22. Watanabe FS, Olsen SR. Test of an ascorbic acid method for determining phosphorus in water and $\mathrm{NaHCO} 3$ extracts from soil. Soil Sci. Soc. Am. Proc.1965;29(6):677-678.

23. SAS. (2002). SAS Institute Inc., Cary, NC, USA. NOTE: SAS Proprietary Software Version 9.00 (TS M0).

24. Duncan DB. Multiple Range and Multiple F-tests. Biometrics.1955;11(1):1-42.

25.Zayeed, A.A.; Magdub, A.B.; Shareha, A.M.; El-Sheikh, A. and Manzally, M. (1991). Conf. of camels in the Arab World. University of Omar ElMukhtar, 1st Ed [Arabic].Tripoli (Libya). pp: 115.

26. Abdallah HR, Faye B. Phenotypic classification of Saudi Arabian camel (Camelus dromedarius) by their body measurements. Emir J Food Agric.2012;24(3):272-280.

27. Eisa MO, Ishag IA, Abu-Nikhaila AM .A note on the relationships between udder morphometric and milk yield of Lahween camel (Camelus dromedarius). Livest Res Rural Develop.2010

28. Wardeh MF, Al-Mustafa M. (1990). Camel breed types in the Arab countries North and West Africa. Proc Arab Symp of camel husbandry and diseases and methods of their control. Alger (Algeria), 24-26 March. pp: 105.

29. Ayadi M, Aljumaah RS, Musaad A Samara EM, Abelrahman MM, Alshaikh MA, et all. Relationship between udder morphology traits, alveolar and cisternal milk compartments and machine milking performances of dairy camels (Camelus dromedarius). Spanish J. of Agric. Res.2013;11(3):790-797.

30. Osman, M.O.E.M. (2006). Udder conformation and milk ability of SheCamel (Camelus dromedarius) in EL- Showak, Eastern Sudan. PhD. Thesis, Department of Dairy Production Faculty of Animal Production University of Khartoum August.

31.El-Agamy EI, Nawar M. Nutritive and immunological values of camel milk: A comparative study with milk of other species. In: Proc. 2nd International Camelid Conference: Agroecons. Camelid Farm, Almaty, Kazakhstan.2000.8-12 Sept. 
32. Konuspayeva G, Faye B, Loiseau G, Levieux D. Lactoferrin and Immunoglobulin contents in camel's milk (Camelus bactrianus, Camelus dromedaries, and Hybrids) from Kazakhstan. J. of Dairy Sci.2007;90:(1):38-46.

33. Bernabucci U, Basirico L, Morera P. Impact of hot environment on colostrum and milk composition. Cell. Mol. Biol.2013;59(1): 67-83.

34. El-Hatmi H, Levieux A, Levieux D. Camel (Camelus dromedarius) immunoglobulin G, $\alpha$-lactalbumin, serum albumin and lactoferrin in colostrum and milk during the early post partum period. J. of Dairy Res.2006;73(3):288-293.

35. Fahmy BGA, Maha MM. (2010). Interrelationships between Somatic cell count and biochemical changes in Egyptian camel milk. SCVMJ, XV (1) 45-72.

36. Mackle TR, Bryant AM, Petc hSF, Hill JP. Auldist MJ. Variation in the composition of milk protein from pasture-fed dairy cows in the late lactation and the effect of grain and silage supplementation. New Zealand Journal of Agricultural Research.1999;42(2) 147-154.

37. Król J, Brodziak A, Litwińczuk Z, Barłowska J. Selected Factors Determining the Content of Lactoferrin, Lysozyme and Immunoglobulins $G$ in Bovine Milk A Search for Antibacterial Agents.2012;107-124.

38. Osman, MMH. Assessment of cows and she-camel colostrum and some factors affecting their chemical composition. M.Sc. Thesis, Department of Dairy Production, Faculty of Animal Production, University of Khartoum.2014.

39.Wilson RT. (1998). Camels. CTA series, Mac Millan Educational Press LTD, London, Uk. Pp: 120-124.

40. Bakheit SA, Bernard F, Ibrahim IE. Effect of improving management system on camel milk production. University of Kordofan Journal of Natural Resources and Environmental Studies, UKJNRES.2015;2(2):13-22.

41. Abdalla EB , Ashmawy AA ,Farouk MH ,Salama OA, Khalil FA, Seioudy AF. Milk production potential in Maghrebi she-camels. Small Ruminant Research.2015;123(1):129-135.

42. Obied AA, Hakem BZ. Milk composition of Libyan Maghrebi camels (Camels Dromedaries) reared under farm and desert conditions. International Conference on Chemical, Environment \& Biological Sciences.2014;92-94.

43. Shuiep ES, El Zubeir IEM, Yousif IA. Compositional Quality of Camel Milk and Some Husbandry Practices Associated with Camel Milk Production in Two Production Systems in Sudan SUST Journal of Agricultural and Veterinary Sciences (SJAVS).2014;15(2) 10-18.
44. Al Haj OA, Al Kanhal HA. Compositional, technological and nutritional aspects of dromedary camel milk. International Dairy Journal.2010;20(12):811-821.

45. Babiker WIA, El Zubeir IEM. Impact of Husbandry, stages of lactation and parity number on yield and chemical composition of dromedary camel milk. Emir Journal of Food and Agriculture.2014;26(4):333-341.

46. Bekele T, Lunderheim N, Dahlbron K. Milk feeding and feeding behaviour in the camel (Camelus dromedarius) during 4 watering regimens. Journal of Dairy Science.2011;94(3):1310-1317.

47. Riyadh SA, Faris FA, Elsyed I, Mohammed AA, Ahmed S. and Moez, A. Effects of production system, breed, parity, and stage of lactation on milk composition of dromedary camels of Saudi Arabia. Journal of Animal and Veterinary Advances.2012;11(1):141-147.

48. Dowelmadina IMM, El Zubeir IEM, Salim ADA, Arabi OHMH. Influence of some factors on composition of Dromedary camel milk in Sudan. Global J. of Animal Scientific Research.2014;2(2):120-129.

49. Mustafa AB, Mohamed EHA, Haroun E, Attia KA, Nikhala MA. Effect of parity on camel milk composition under traditional pastoral and farmed systems in Sudan. International Journal of advances in pharmacy, biology and chemistry (IJAPBC).2014; 3(2):266-272.

50. Gorban AMS, Izzeldin OM. Mineral content of camel milk and colostrum. J. Dairy Res.1997;63(3):471-474.

51. Mehaia MA, Hablas MA, Abdel-Rahman KM, El-Mougy SA. Milk composition of Majaheim, Wadah and Hamra camels in Saudi Arabia. Food Chem.1995;52(2):115-122.

52. Shawket MS, Ibrahem AH. (2012). Impact of long-Term feeding atriplex (Saltbush) on camel's milk production under arid conditions. in: Proceedings of the 3rd Conference of the International Society of Camelid Research and Development.

53. Elnour AAHM,Bakheit SA. (2012). The effect of parity number on some mineral level rations in camel's milk. A case study: North Kordofan State, Sudan. in: Proceedings of the 3rd Conference of the International Society of Camelid Research and Development.

54. Musaad AM, Faye B, Al-Mutairi SE. Seasonal and physiological variation of gross composition of camel milk in Saudi Arabia. Emir. J. Food Agric.2013;25(8):618-624. 